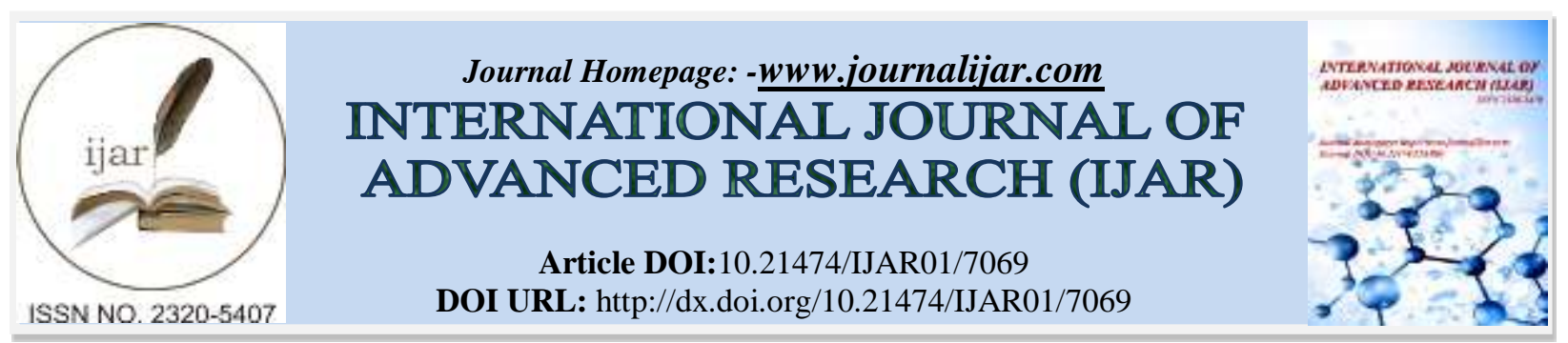

RESEARCH ARTICLE

\title{
CHEMOPREVENTION OF LUNG CARCINOGENESIS IN STRAIN BALB/C MICE WITH POLYPHENOLS OF MAHKOTA DEWA (Phaleria macrocarpa) FROM INDONESIAN HERBAL.
}

Theopilus Wilhelmus Watuguly.

\section{Manuscript Info}

(..........................

Manuscript History

Received: 10 March 2018

Final Accepted: 12 April 2018

Published: May 2018

Keywords:-

Polyphenols, Mahkota Dewa (Phaleria Macrocarpa), Lung Carcinogenesis, Balb/C Strain Mice

\section{Abstract}

Backgroud and objective: Polyphenols of Mahkota Dewa (Phaleria macrocarpa) has potential as anticancer that is expected to inhibit lung carcinogenesis, but it has not been widely studied. This study aims to prove the role of Mahkota Dewa polyphenols to inhibit the progression of lung carcinogenesis development in mice.

Methods: The design used in this study is posttest serial control group design with 40 strain Balb/c mice as samples, aged 1-2 weeks, weighted 20-30 g, and in healthy condition. All mice were induced using $\mathrm{B}(\mathrm{a}) \mathrm{P}$ then were randomized into 2 groups: the control group and the $50 \mathrm{mg}$ polyphenols treatment group. The development of lung tumor was observed with tissue surgery at week-8, -17 , and -26 . The examination of lung carcinogenesis incidence was done using $\mathrm{H} \& \mathrm{E}$ staining.

Results: The data were analyzed using Kruskal-Wallis, Mann-Whitney, with significance level of $\mathrm{p}<\alpha(0.05)$. Oral administration of Mahkota Dewa's polyphenols significantly showed the inhibition of lung carcinogenesis incidence in the treatment group at week-8, -17, and -26 $(\mathrm{p}=0.000)$. The incidence of lung carcinogenesis in the control group at week-8, -17 , and -26 were $2.32 \pm 0.26$ and $3.93 \pm 0.46$; while in the treatment group were $1.88 \pm 0.38$ and $0.88 \pm 0.22(\mathrm{p}=0,000)$.

Conclusion: The administration of Mahkota Dewa's polyphenols was effective to inhibit lung carcinogenesis in Balb/c strain mice.

Copy Right, IJAR, 2018,. All rights reserved.

\section{Introduction:-}

Mahkota Dewa (Phaleria macrocarpa) is a medicinal plant (herbal) which is originally come from Indonesia, has been known empirically that it has anticancer activity and the potential to inhibit cancer development in many scientific studies (Wardhani HR, et al, 2004; Rahmawati E, et al, 2006; Widyasari A, et al, 2006; Faried A, et al, 2007). This inhibition activity is thought to be related with the polyphenol compounds in Mahkota Dewa. Based on the phytochemical analysis and standardization, polyphenol is one of the main compound found in fruit of Mahkota Dewa (Lisdawati E, 2002; Watuguly T, $d k k$, 2005; Faried A, et al, 2007).

Polyphenol is a natural phenolic compound that has anticancer properties and potential as inhibitor of cancer growth (Zhai S, et al, 2008; Singh RP, et al, 2005). The study conducted by Frei B, Higdon JV (2003) showed that polyphenols has anticancer activity and play a role in inhibition of cancer. As an anticancer, polyphenols of Mahkota Dewa is expected to inhibit cell proliferation and inducing apoptosis. 
Polyphenols of Mahkota Dewa is expected as potential chemopreventive to disrupt or reversing the carcinogenesis process by acting on intracellular signalling of molecular tissue that is involved in iniation and/or promotion stage, and also can stop or reversing the developmental stage of cancer (Manson M, 2003; Surh YJ, 2003). The use, effectivity, and the utilization of Mahkota Dewa had been demonstrated as do not have any side effects, both empirically and in pre-clinical studies (Soeksmanto A, 2006 ${ }^{\mathrm{a}, \mathrm{b}}$ ). Until recently, polyphenols of Mahkota Dewa has never been reported as to its inhibition of lung carcinogenesis in experimental animals through the process of cell proliferation and apoptosis that are considered as targets in the prevention of carcinogenesis; so it is necessary to do further research in-vivo.

Various researchs had began to studied about the possible involvement of molecular mechanisms such as cell cycle, cell proliferation, regulation of apoptosis, and tumor suppressor genes in the pathogenesis and progession of lung cancer (Esposito et al, 2002; Groeger, et al, 2000, 2004 dan Caputi M, et al, 2005). The disruption of homeostatic which regulate cell proliferation and cell death (apoptosis) may contribute to the development and growth rate of tumor. This suggests that the ability to induce apoptosis and inhibit proliferation are considered as the primary factor in determining the success of chemopreventive agents (Benerjee S, et al, 2005).

Chemotherapy and radiotherapy programs are the main therapy for most patients with lung cancer, but the expected results with such therapy have not been helpful and the result itself is still limited because most patients often experiencing a relapse (Zochbauer-Muller S, et al, 2002; Benerjee S, et al, 2005). The lots of failure in chemotherapy and radiotherapy of lung cancer usually associated with the failure of anticancer agents in inducing the programmed cell death (apoptosis) of cancer (Fisher DE, 2004). In addition to chemotherapy and radiotherapy, the management of lung cancer can be done with chemopreventive measures (prevention). The aim of the chemopreventive measures are to intervent the cancer by administering natural ingredients that can inhibit, delaying, and blocking or reversing the carcinogenesis process, which can be used as protection from carcinogenic exposure and reduce the risk of lung cancer (Benerjee $\mathrm{S}$, et al, 2006b).

\section{Methods:-}

\section{Research Samples:-}

A total of 40 of strain Balb/c mice aged 1-2 weeks were adapted for a week in laboratorium of experimental animals, which the animals were caged in a sterile manner with adequate lighting.

\section{Induction with B(a)P:-}

The lung cancer was induced according to the carcinogen test conducted by Murwanti R, et al, 2004; Benerjee S, et $a l, 2006^{\mathrm{a}, \mathrm{b}}$. The first induction was done on day- 1 with a dose of $0.2 \mathrm{~mL} / 0.025 \mathrm{cc}$. The second induction was done on day- 8 with a dose of $0.4 \mathrm{~mL} / 0.025 \mathrm{cc}$ and the third induction was done on day- 15 with a dose of $0.8 \mathrm{~mL} / 0.025 \mathrm{cc}$. Each young mice got (received) an induced lung tumor subcutaneously in the sub-scapular region with $0.1 \mathrm{~mL}$ of $\mathrm{B}(\mathrm{a}) \mathrm{P}$ suspension with a concentration of $0.2 \mathrm{mg}$ which was already diluted into DMSO (single dose). Carcinogen was used within 1 hour after emulsification. Once injected, the young mice were allowed to live with their mother, were given water and food ad libitum during the weaning process. DMSO was not toxic so it was safe to used as diluent solution and was diluted with B(a)P (inductor).

\section{Treatment in Strain Balb/c Mice:-}

As much as 8 mice were sacrificed to determine the growth of tumor cells in a row at week- 4 and week- 5 to observed the carcinogenesis development into hyperplasia and dysplasia stadium in lung epithelial cells of mice.

Entering week-5, the strain Balb/c mice that were already into hyperplasia stadium were divided into 2 groups by random allocation and were treated as follows:

\begin{tabular}{|l|l|l|}
\hline$-\quad$ Group C & $:$ & $\begin{array}{l}\text { a total of } 15 \text { mice in the control group, untreated with polyphenols of Mahkota Dewa until } \\
\text { week-26. }\end{array}$ \\
\hline$-\quad$ Group X & $:$ & $\begin{array}{l}\text { a total of } 15 \text { mice in the treatment group were administered orally with polyphenols of } \\
\text { Mahkota Dewa at a dose of } 50 \mathrm{mg} / \mathrm{kg} / \mathrm{mice} / \mathrm{day} \text { from week-5 and continued until week-26. }\end{array}$ \\
\hline
\end{tabular}

The mice from 2 groups (control and treatment) were terminated at week-8, -17, and -26 to study the development of stadium with different time intervals. All of lung organs were excised and washed with $0.9 \% \mathrm{NaCl}$ solution, were dried and fixated with $10 \%$ of formaldehyde buffer for 24 hours, and then the paraffin blocks were ready to made. 
As much as 5 lung lobes were cut with each slide has 4 microns sized with 4 pieces of tissues, then the observations were made.

\section{H\&E Staining:-}

The next process included the processing of histological preparation through the stages of fixation, dehydration, impregnation, and embedding. The tissues of 2 groups that had been made into paraffin blocks were cut to 4 microns thick and then were stained using Hematoxylin Eosin $(\mathrm{H} \& \mathrm{E})$ to calculate the incidence of hyperplasia and dysplasia in the bronchiole epithelium of lung tissue with light microscope using 400X magnification.

After being stained with H\&E, the slides were observed for hyperplasia and dysplasia incidence, also the inhibition in bronchiole epithelial at week-8, -17 , and -26 both in the control group and treatment group. The calculation of changes in hyperplasia and dysplasia also the inhibition were in accordance with calculation method by Benerjee $\mathrm{S}$, et al (2004) i.e. \% inhibition= $(1-\mathrm{T} / \mathrm{C}) \times 100$.

Observations to Hyperplasia- Dysplasia:-

The number of bronchial epithelial undergo hyperplasia and dysplasia which is observed with $\mathrm{H} \& \mathrm{E}$ staining. Excessive cell growth which occurs does not indicate malignancy which showed hyperplasia. On epithelium, it is shown that cell core grows more, but the cell shape still looks the same. Dysplasia Development showed growth abnormalities with the changes in the structure and morphology of the cells. The size of cell core is large/small, cell shape is varied, the cell is not uniform, the color is darker, the structure of the cell core is irregular and the ratio of cell core and cytoplasm are rising. How to measure it by calculating the number of epithelial bronchioles undergo hyperplasia and dysplasia, it is observed as a whole and calculated the average of the Light microscope with magnification 400X with scale/unit ratio/cell count (Benerjee S, et al, 2005; Benerjee S, et al, 2006).

\section{Data Analysis Technique:-}

Incidence data of lung carcinogenesis is a ratio scale. The data were descriptively analyzed and were presented in the form of mean, median, mode, and standard deviation; then considered to have normal distribution or not by assessing the histograms and boxplot. Before the data were analyzed, the normality test and homogeneity test were performed first. Data analysis included non-parametric test of Kruskall-Wallis then followed with Mann-Whitney test to determine the incidences of lung cancer, with significant level of $p<0.05$ and confidence interval of $95 \%$. The data obtained were statistically analyzed using SPSS ver.19.

\section{Results and Discussion:- \\ Result:-}

The incidence of hyperplasia and dysplasia:-

After the mice were overall terminated at week-26, the lung organs (Figure 1) were isolated and were made into paraffin blocks. H\&E staining were done to observed the hyperplasia and dysplasia of bronchiole epithelial. Figure $1 \mathrm{~A}$ is the result of this study. 

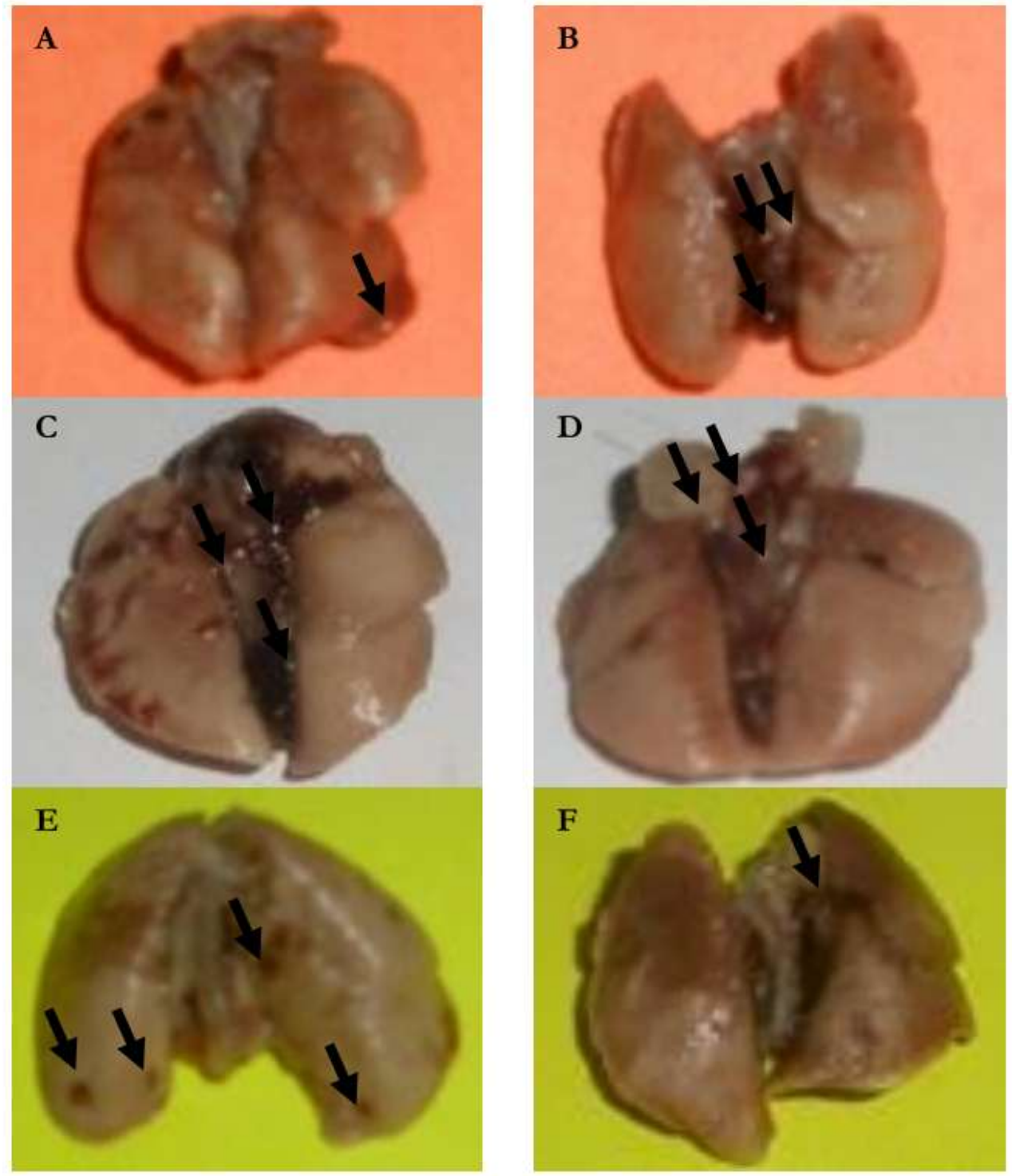

Figure 1:-The lung organs images of strain Balb/c mice in the control group and treatment group. The lung organs had been fixated in 10\% neutral buffered formalin for 24 hours. The black arrows indicate the nodules of lung tumor. In Figure 1.A (top) A,B indicate the surgery at week-8; C,D indicate the surgery at week-17; and E,F indicate the surgery at week- 26.

The inhibition and incidence of hyperplasia and dysplasia in bronchiole epithelial at week-8, -17 , and -26 both in the control group and the treatment group can be seen in Table 1 below.

Table 1:-The Changes of Hyperplasia and Dysplasia along with the Inhibition in Bronchiole Epithelial at week-8, 17, and -26 Induced by B(a)P in the Control Group and Treatment Group.

\begin{tabular}{|l|c|c|c|c|c|c|}
\hline \multirow{2}{*}{ Group } & \multicolumn{2}{|c|}{ \% Incidence of Hyperplasia-Dysplasia } & \multicolumn{3}{c|}{ \% Inhibition } \\
\cline { 2 - 7 } & week-8 & week-17 & week-26 & week-8 & week-17 & week-26 \\
\hline B(a)P & 58 & 68 & 96 & 0 & 0 & 0 \\
B(a)P + Polyphenols & 47 & 31 & 21 & 18.96 & 54.41 & 78.12 \\
\hline
\end{tabular}

\% Inhibition $=(1-\mathrm{T} / \mathrm{C}) \times 100, \mathrm{n}=15$

Table 1 shows the protective effects of Mahkota Dewa polyphenols throughout the lung carcinogenesis that was induced by B(a)P. In this study the hyperplasia incidence were 58\% in the control group and then fell to $47 \%$ in the treatment group, so the inhibition percentage by polyphenols of Mahkota Dewa was $18.96 \%$. At week-17 it was 
$68 \%$ in the group exposed by B(a)P, $31 \%$ in the treatment group, thus the inhibition percentage recorded was $54.41 \%$ after administration of Mahkota Dewa polyphenols. At week-26 it was $96 \%$ in the control group, and there was a decrease in the hyperplasia incidence to $21 \%$ in the treatment group, which showed $78.12 \%$ after the given treatment.

Based on this study results, the histopathological changes in the experimental animals may occur but the changes occur until the development of dysplasia in the control group. While in the treatment group, the exposure of Mahkota Dewa polyphenols could delay the formation and development of hyperplasia into dysplasia at the postinduction of carcinogens.

In the control group, the tumor incidence entered the development stage of hyperplasia and progressed into dysplasia. While in the treatment group the inhibition of tumor development occurred after exposure of Mahkota Dewa polyphenols so it did not enter into dysplasia development stage. The results of histopathological examination using H\&E staining method showed visible changes in the bronchiole epithelial. That changes included the proliferation of bronchiole epithelial, hyperchromatic nucleus, enlarged nucleus, and cytoplasm becomes narrower and there was found an image of mitosis.

Based on Figure 2, at week-8 there were noticeable changes of hyperplasia in bronchiole epithelial cells in the control group, while there were no changes of hyperplasia in bronchiole epithelial cells in the treatment group. In Figure 3, at week-17 the development of hyperplasia in the control group remained the same, while the administered Mahkota Dewa polyphenols in the treatment group has affected the majority of epithelial cells so that it looks normal. At week-26, there were histopathologic changes towards dysplasia in the control group, but in the treatment group there were no changes towards dysplasia and still showed hyperplasia.

In the control group at week-8 and week-17, there were excessively cell growth in the bronchiole epithelial that showed no malignancy and showed hyperplasia, in the epithelial cells showed a lot of cell nucleus growth (Figure 2A,B). The histopathological observation on bronchiole epithelial after 26 weeks showed dysplasia, in which there were growth abnormalities that lead to changes in the structure and morphology of the cells. The size of the cell nucleus was bigger/smaller, the cell structure had been varied and the shape was not uniform, the color looks darker and the cell nucleus had been irregularly arranged (polarization), also the ratio of cell nucleus and cytoplasm were increased and the chromatin was clumped (darker) (Figure 2C).

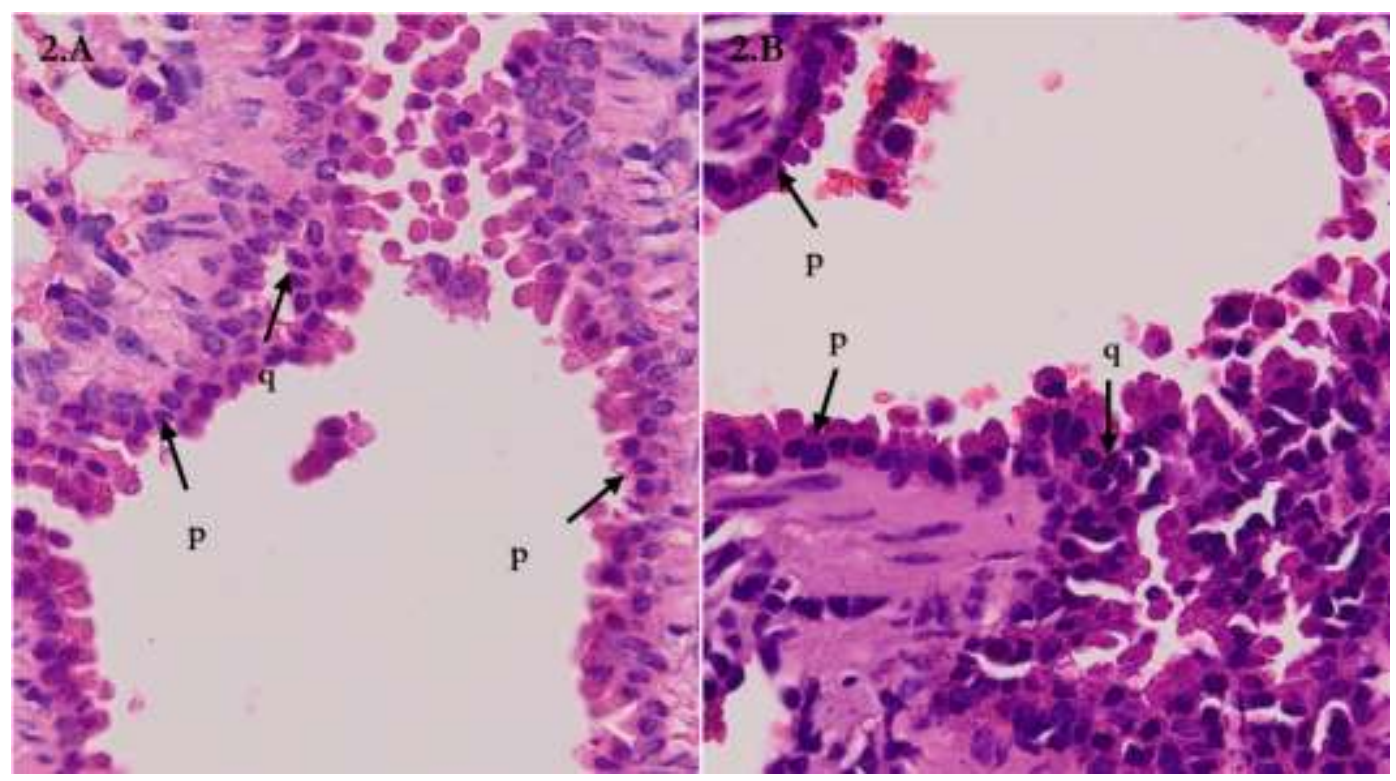




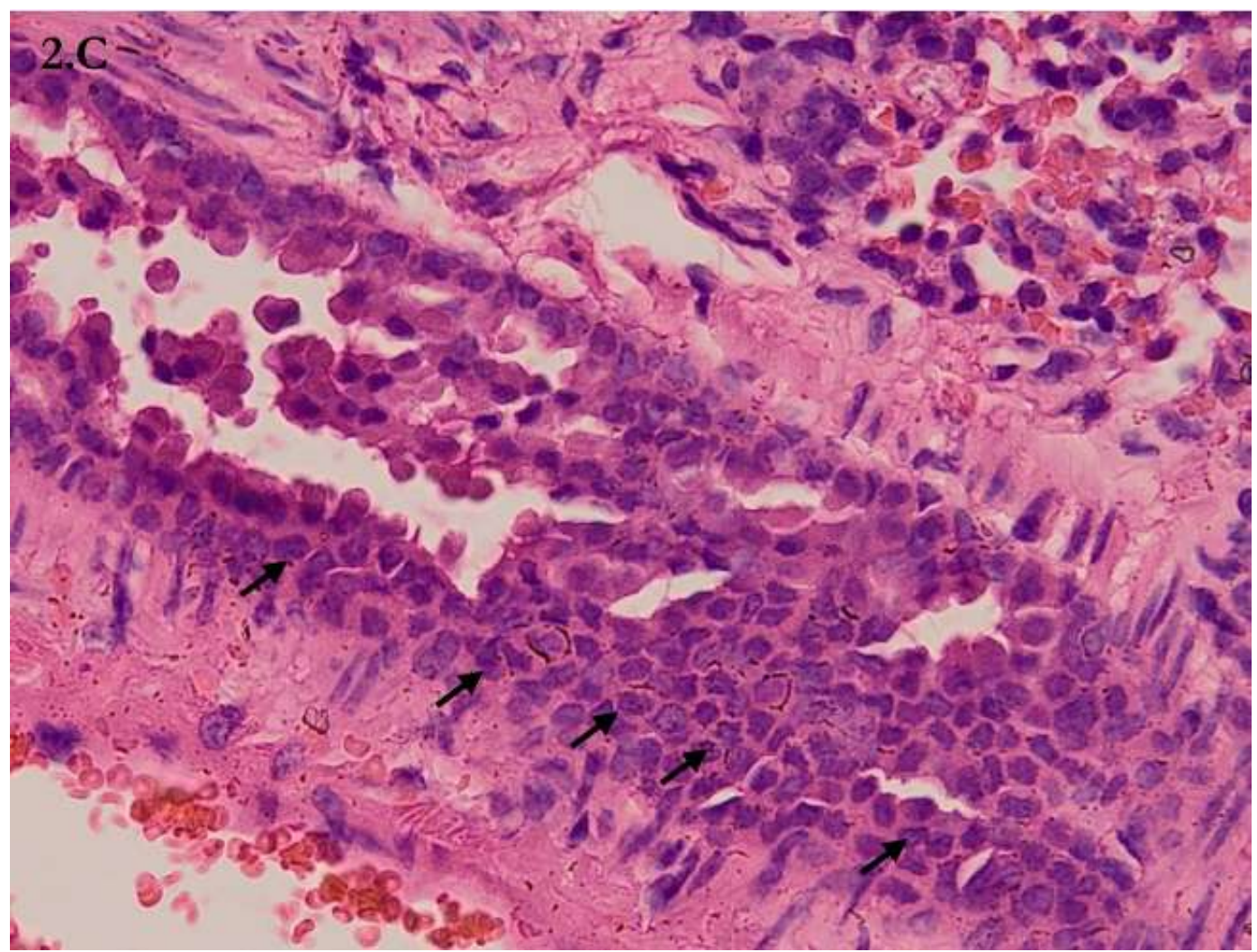

Figure 2:-The histopathology of bronchiole epithelial in the control group at week-8 (2.A), week-17 (2.B), and week-26 (2.C); the results from B(a)P induced. At week-26, the size of cell nucleus look bigger/smaller, the cell shape had been varied where the cells were not uniform, the color was darker, the structure and composition of cell nucleus were irregular (polarization), and the increase of ratio of cell nucleus and cytoplasm showed dysplasia $(\mathrm{p}=$ few cells still appear normal; $q=$ there was excessive cell growth but the cells still appear the same [arrow]) showed hyperplasia (Hematoxylin-Eosin [H\&E] staining, with magnification of 400X).

\section{Univariate and Bivariate Analysis:- \\ Changes of Hyperplasia and Dysplasia Lesions:-}

Based on the statistical analysis (Chart 3) at week-8, the average number observed in the bronchiole area in the control group was $23.32 \pm 0.26$ and in the treatment group was $1.88 \pm 0.38$. At week-17, the average number in the control group was $2.64 \pm 0.57$ and in the treatment group was $1.16 \pm 0.16$. At week-26, the average number in the control group was $3.93 \pm 0.46$ and in the treatment group was $0.88 \pm 0.22$. 


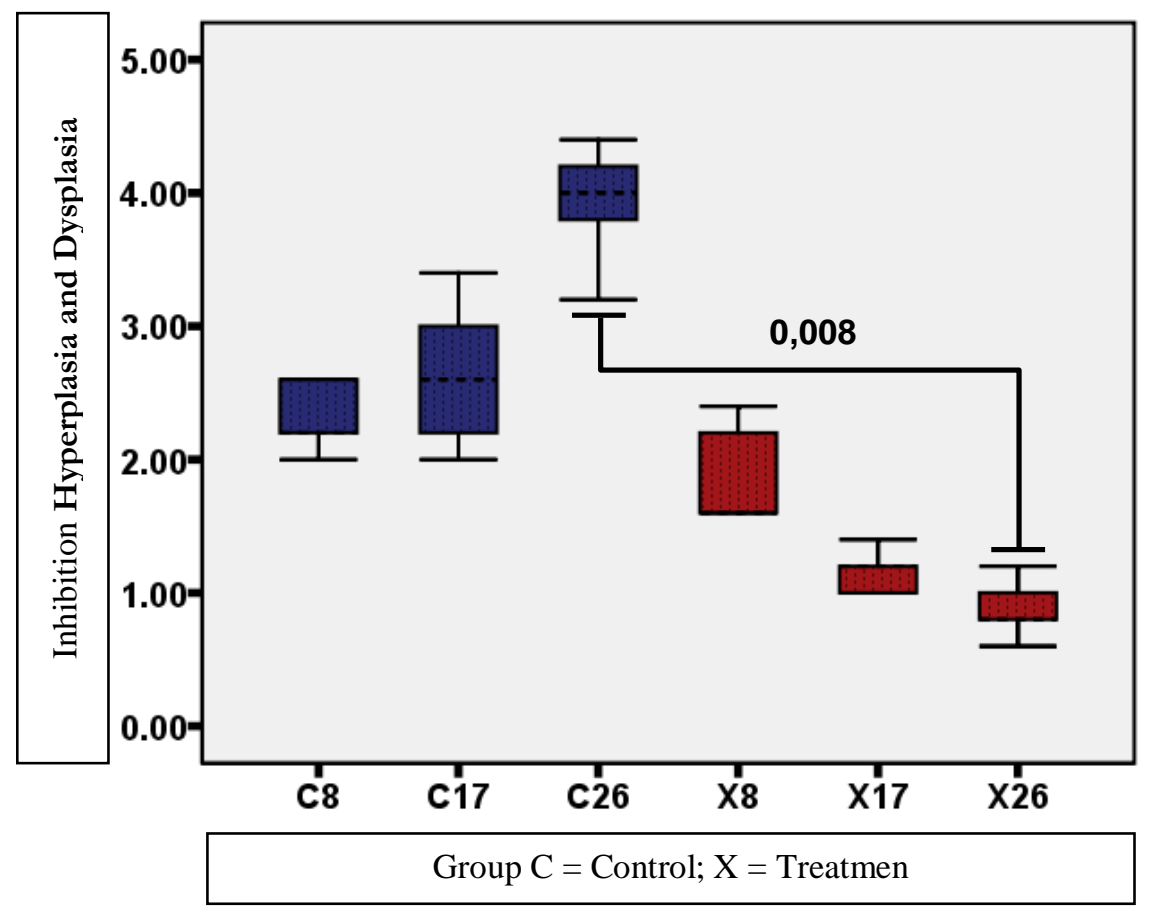

Figure 3:-The boxplot graph of lung carcinogenesis inhibition in the control group and treatment group by polyphenols of Mahkota Dewa. The administration of Mahkota Dewa's polyphenols inhibited the development of bronchiole epithelial in the lungs of strain Balb/c mice.

These results indicate that, in the control group of carcinogens at week-8, there was an increase of lung carcinogenesis incidence, and continued to increase until week-17 and 26. While in the group that was exposed to polyphenols of Mahkota Dewa, there was a decrease of lung carcinogenesis incidence at week-8, -17 , and -26 . Statistical test using Kruskall-Wallis test showed significant improvement $(\mathrm{p}=0.000)$ (see appendix 12). Then, the further differences between the experimental groups were analyzed using Mann-Whitney test.

\section{Discussion:-}

To determine the role of antitumor compounds that precisely inhibit the growth of tumor cells, it would require an in-vivo study using experimental animals. Various methods of tumor inductions require considerable time with large doses of carcinogens to grow the tumor as well as the necessary of certain strains of experimental animals with high sensitivity level. Sensitivity towards inductor is affected by species, strain, age, gender, and target organs. In this study, the use of experimental animals with young age is expected to have high sensitivity towards $\mathrm{B}(\mathrm{a}) \mathrm{P}$ inductor than the old age. The use of young mice is expected to have high sensitivity when the test takes place.

This study uses young age of strain Balb/c mice with the consideration that this strain has the highest incidence of spontaneous tumor/cancer and also highly responsive to chemical induction of lung cancer (Malkinson AK, 2001; Bonner AE, et al, 2004). Therefore, the strain Balb/c mice are suitable to be identified as chemopreventive agents of lung tumorigenesis (Kassie F, et al, 2008). While the carcinogen used is $\mathrm{B}(\mathrm{a}) \mathrm{P}$, the main compound found in tobacco smoke which is a carcinogen that can increase DNA damage (Duarte RL de M, et al, 2005; Benerjee S, et al, 2006b) and causes lung cancer.

In the control group induced by B(a)P, although the induction was discontinued at week-4, but development of lung cancer continued until week-26. This was caused by the ability of B(a)P in inducing glutathione-S-transferase (GST) enzyme, which is a phase II metabolic enzyme. Additionally, B(a)P can induce cell proliferation caused by overexpression of enzyme involved in synthesis of nucleotide and DNA, also it regulates the differentiation that causes cells to proliferate uncontrollably (Giovannini C, et al, 2007). The results of this study are supported by a research conducted by Benerjee S, et al (2005), which stated that during the lung carcinogenesis in strain A mice caused by B(a)P there were changes in cellular and histopathological cells identified as hyperplasia, dysplasia, insitu carcinoma, and invasive carcinoma. Another research by Estensen RD, et al (2004) showed the results of the 
study using B(a)P as carcinogen, capable of causing the development of hyperplasia in strain $\mathrm{A} / \mathrm{J}$ mice at week -3 , adenoma appeared at week-12, and carcinoma appeared at week-26 post-administration of B(a)P. While research conducted by Yang Y, et al (2007) showed that the lung carcinogenesis in strain A/J mice in the control group developed until at week-18 before it was terminated.

The observation results based on histopathological image of lung tissue of strain Balb/c mice showed that thre were specific changes in lung cells, the bronchiole epithelial cells were seen arranged into two layers although some of the epithelial cells were still arranged into one layer. In the control group, the bronchiole epithelial cells entered the stage of hyperplasia and developed into dysplasia. While in the treatment group there was an inhibition of hyperplasia to developed into dysplasia after administration of Mahkota Dewa's polyphenols. The results of histopathological examination using H\&E staining method, showed visible changes in the bronchiole epithelial. These changes included proliferation of bronchiole epithelial, hyperchromatic nucleus, enlarged nucleus, and cytoplasm becomes narrower and there was found an image of mitosis. This observation is in accordance with the research conducted by Benerjee S, et al (2005); Benerjee S, et al (2006) that there were found changes in the tumor cells such as change in the chromatin nucleus becomes more dense and darker (hyperchromatic), abnormal image of mitosis, narrower cytoplasm, enlarged nucleus, and anaplasia (the cell form becomes larger and irregular).

Inhibition of the development of bronchiole epithelial in changes of hyperplasia into dysplasia in the treatment group were due to the effect of Mahkota Dewa's polyphenols that inhibited the signal transduction process of growth factors or other factors that induced cell growth. Polyphenols had been proved to have anticancer properties because it can act as chain breakers, radical scavengers, and metal chelator depending on its chemical structure that affects the antioxidant value of this polyphenol. Polyphenolic compounds basically have the ability to protect DNA and to protect/inhibit oxidative stress. Thus, many of biological actions of polyphenols are associated with anticancer properties. Conversely, the pro-oxidant of polyphenols has the opposite effect on the process of cell physiology. As an antioxidant, polyphenols improve cell endurance, and as pro-oxidant, polyphenols induce apoptosis and cell death also inhibit cell proliferation (Rice-Evans CA, et al, 2005; Giovannini C, et al, 2007).

Polyphenol compounds can affect the whole process of carcinogenesis by several mechanisms. Specifically, polyphenols contributed in the resistance of oxidative stress (Yao LH, et al, 2004; Porrini M, et al, 2005) and in this process, polyphenols contributed in the early prevention and development of cancer. Actually, by modulating the oxidative stress in cancer cells, polyphenols can affect the signal transduction, activation of redox-sensitive transcription factors and expression of specific genes that may affect the proliferation and apoptosis of cells (Sang S, et al, 2005; Rahman I, et al, 2006).

Furthermore, various studies indicated that polyphenols can directly modulate different points in the procss of apoptosis and/or expression of regulatory proteins, such as the release of cytochrome $\mathrm{C}$ enzyme by activating caspase-9 and caspase-3 (Ong CS, et al, 2004; Shimizu M, et al, 2005; Michael G, et al, 2005), the increase of caspase-8 (Selvendiran K, et al, 2006), the down-regulation of Bcl-2 and Bcl-xl expression, and the increase of Bax and Bak expression (Kuo PL and Lin CC, 2003; Lee HJ, et al, 2005). Several sources had demonstrated the mechanism of polyphenols, which aims to explained the effectivity of chemopreventive agents against tumor cells (Thomasseet SC, et al, 2007). In principle, polyphenols capable of (1) suppress the overexpression of pro-oxidant enzymes which affecting the development of cancer, (2) obstruct the activation of transcription factors and regulate target genes that involved in the survival and proliferation of cells, (3) induce apoptosis.

The results of this study showed changes in hyperplasia at week-8, continued until week-17. Changes of hyperplasia into dysplasia in the bronchiole epithelial cells on histopathological observation occurred at week-26 in the control group. While in the treatment group until week-26 showed further inhibition on the formation of bronchiole lesions. Significant differences between control group and treatment group were demonstrated through statistical test with $(\mathrm{p}=0.000)$. Since the value of $\mathrm{p}<0.05(0.000)$, the first hypothesis which stated that polyphenols of Mahkota Dewa can inhibit lung carcinogenesis in strain Balb/c mice is accepted. Histopathological analysis showed the role of Mahkota Dewa's polyphenols capable of limiting or inhibiting the process of lung carcinogenesis and delaying the development of lung carcinogenesis at post-initiation phase.

The results of this study are similar with the research conducted by Watenberg LW, et al, where the administration of polyphenon $\mathrm{E}$ (polyE) at low dose was able to inhibit all stadium of the development of hyperplasia into adenocarcinoma in lung carcinogenesis of strain A/J mice induced B(a)P (Watenberg LW, et al, 2000). Another 
research by Yang CS, et al (2009), found that polyE and EGCG significantly inhibited lung tumorigenesis in strain A/J mice. Also mentioned in the research by Yang G, et al (1997) who studied the administration of black tea in strain $\mathrm{A} / \mathrm{J}$ mice, showed that the black tea which was given in drinking water capable to delayed or inhibited the development of lung tumor. Wang ZY, et al, found that the administration of green tea, black tea, and combination of the two, capable to prevented the development of skin tumor in strain SKH-1 mice (Wang ZY, et al, 1994). Scientifically, the inhibition occurs because polyphenols are considered as promising agents for chemopreventive of cancer (Yang CS and Wang ZY, 1993; Banerjee S, et al, 2005). Polyphenols have anticancer activity because of its function as radical scavenger and metal chelator (Archivio MD', et al, 2008). The delayed progression on histopathological changes of hyperplasia into dysplasia, in the treatment group may be associated with the increase of stable apoptosis, will provide the important protective activity on various chemopreventive agents.

The growth of lung cancer is the same as other types of cancer through 3 phases: initiation phase, promotive phase, and progressive phase. The process of carcinogenesis need to be control through physiologic as well as pharmacologic process in the stage of preneoplastic so that the further development of promotive phase can be hold and prevented. This control can be done through preventive measures such as avoidance to various agents known to induce cancer, improve the resistance to cancer, changing lifestyles and the use of chemopreventive agents (chemoprevention). Chemoprevention involve substances that can delaying or stopping the process of carcinogenesis resulting in lower risk of cancer invasion process. By studying various pathways such as cell proliferation and apoptosis, it was to be expected the use of chemoprevention to inhibit the cell proliferation and induce apoptosis (Sun S-Y, et al, 2004). Increased or uncontrolled proliferation and impaired apoptosis play a role in determining the accumulation of malignant cells and cause the formation of multistage carcinogenesis.

Thus, it can be concluded that the polyphenols of Mahkota Dewa has anticancer activity which plays a role in the inhibition of lung carcinogenesis in experimental animals through the mechanism of lung carcinogenesis inhibition.

\section{Conclusion:-}

Based on the results of analysis and the discussion of this research, it can be concluded that polyphenols of Mahkota Dewa proved to be effective to inhibit lung carcinogenesis which is marked by the inhibition of hyperplasia changes into dysplasia in the bronchiole epithelial in the strain Balb/c mice. It is recommended to do further research on the role of proteins and enzymes that cause damage to the lung tissue of strain Balb/c mice.

\section{Limitation:-}

This research in limited onlu on patologic parameter. For other parameter like imunology parameter do not yet. For furture research adding variable in relation with in this study is needed.

\section{Acknowledgement:-}

1. This research was financially supported by Ministry of Technology, Research and Higher Education through the grants of Doctoral and the grants of Postgraduate Education.

2. Our thanks to the entire staff of Pathology Laboratory of Faculty of Medicine, Gadjah Mada University and Sardjito Hospital Yogyakarta, also Anatomical Pathology Laboratory of Diponegoro University and Kariadi Hospital Semarang for the assistance to make preparations using H\&E staining, and performed IHC cut in the laboratory.

3. Also thanks to the staff of Integrated Research and Testing Laboratory, Division of Pre-Clinical Service and Experimental Animals Development (LPPT-Division of LP3HP) Gadjah Mada University Yogyakarta for the assistance to the research of experimental animals in the laboratory.

4. And also the staff of Integrated Research and Testing Laboratory, Division of Unit I Research Service of Gadjah Mada University (LPPT-Unit I) for the permission to conducted the research to performed fractionation and total analysis of polyphenols in the laboratory. 


\section{References:-}

1. Archivio MD', Santangelo C, Scazzocchio B, Vari R, Filesi C, Masella R, Giovannini C. Modulatory effects of polyphenols on apoptosis induction: relevance for cancer prevention. Int. J. Mol. Sci. 2008; 9: 213-228.

2. Banerjee S, Manna S, Mukherjee S, Pal Debalina, Panda CKr, Das S. Black tea polyphenols restrict benzo(a)pyrene-induced mouse lung cancer progression through inhibition of Cox-2 and induction of caspase-3 expression. Asian Pacific J Cancer Prev 2006a; 7: 661-666.

3. Banerjee S, Manna S, Saha P, Panda CKr, Das S. Black tea polyphenols suppress cell proliferation and induce apoptosis during benzo(a)pyrene-induced lung carsinogenesis. European Journal of Cancer Prevention, 2005; 14: 215-221.

4. Banerjee S, Panda CKr, Das S. Clove, a potential chemopreventive agent for lung cancer. Carcinogenesis 2006b; 27(8): 1654-1654.

5. Bonner A. E, Lemon W. J, Devereux T. R, Lubet R. A, You M. Molecular profiling of mouse lung tumors: association with tumor progression, lung development and human lung adenocarcinoma. Oncogene 2004; 23: 1166-76.

6. Caputi M, Russo G, Esposito V, Mancini A, Giordano A. Role of cell-cycle regulators in lung cancer. Journal of Cellular Physiology 2005; 205: 319-327.

7. Duarte RL de M, Paschoal MEM. Molecular markers in lung cancer: prognosis role and relationship to smoking. J. Bras. Pneumol. 2005; 32(1): 56-65.

8. Esposito V, Groeger AM, De Luca L, Di Marino M, Santini D, Marchei P, Baldi F, Wolner E, Baldi A. 2002. Expression of surface protein receptors in lung cancer. Anticancer Res 22(6C):4039-4043.

9. Estensen RD, Jordan MM, Wiedmann, Galbraith AR, Steele VE, Wattenberg. Effect of chemopreventif agents on separate stages of progression of benzo(a)pyrene induced lung tumors in A/J mice. Carcinogenesis 2004; 25(2): 197-201.

10. Fisher DE. Apoptosis in the cancer therapy: crossing the threshold. Cell 2004; 78: 539-542.

11. Frei B and Higdon J. V. Antioxidant activity of tea polyphenols in vivo: evidence from animal studies. Journal of Nutrition 2003; 133: 3275S-3284S.

12. Giovannini C, Scazzocchio B, Vari R, Santangelo C, Archivio D’ M and Masella R. Apoptosis in cancer and artherosclerosis: poliphenol activities. Ann Ist Suoer Sabita 2007; 43(4): 406-416.

13. Goldfarb R, Mineo TC, Baldi A, Wolner E. 2004. Prognostic value of Groeger AM, Caputi M, Esposito V, Baldi A, Rossiello R, Santini D, Mancini A, Groeger AM, Caputi M, Esposito V, Baldi A, Rossiello R, Santini D, Mancini A, Kaiser HE, Baldi F. 2000. Expression of p21 in non-small cell lung cancer relationship with PCNA. Anticancer Res 20(5A):3301-3305.

14. Groeger AM, Caputi M, Esposito V, Baldi A, Rossiello R, Santini D, Mancini A, Kaiser HE, Baldi F. 2000. Expression of p21 in non-small cell lung cancer relationship with PCNA. Anticancer Res 20(5A):3301-3305.

15. Groeger AM, Esposito V, De Luca A, Cassandro R, Tonini G, Ambrogi V, Baldi F, Goldfarb R, Mineo TC, Baldi A, Wolner E. 2004. Prognostic value of immunohistochemical expression of p53, bax, Bcl-2 and Bcl-xL in resectednon-small-cell lung cancers. Histopathology 44(1):54-63.

16. Kassie F, Matise I, Negia M, Upadhyaya P, Hecht SS. Dose-dependent inhibition of tobacco smoke carcinogeninduced lung tumorigenesis in A/J mice by indole-3-carbinol. Cancer Prev. Res. 2008; 1(7): 568-576.

17. Kuo PL, Lin CC. Green tea constituent (-)-epigallocatechin-3-gallate inhibits Hep G2 cell proliferation and induces apoptosis through p53-dependent and Fas-mediated pathways. J Biomed Sci 2003; 10: 219-27.

18. Lee HJ, Wang CJ, Kuo HC, Chou FP, Jean LF, Tseng TH. Induction apoptosis of luteolin in human hepatoma HepG2 cells involving mitochondria translocation of Bax/Bak and activation of JNK. Toxicol Appl Pharmacol 2005; 203: 124-31.

19. Malkinson AK. Primary lung tumors in mice as an aid for understanding, preventing, and treating human adenocarcinoma of the lung. Lung Cancer 2001; 32: 265-79.

20. Manson M. Cancer prevention- the potential for diet to modulate molecular signaling. Trends Mol Med. 2003; 9:11-18.

21. Michael G, Watjen W, Niering P, Steffan B, Thi QH, Chovolou Y, Kampkotter A, Bast A, Proksch P, Kahl R. Pro-apoptosis effects of the flavonoid luteolin in rat H4IIE cells. Toxicology 2005; 206: 337-48.

22. Minna JD, Roth JA, Gazdar AF. Focus on lung cancer (review). Cancer Cell 2002; 1:49-52.

23. Murwanti R, Meiyanto E, Nurrochmad A and Kristina SA, 2004. Efek ekstrak etanol rimpang temu putih (Curcuma zedoria Rosc.) terhadap pertumbuhan tumor paru fase post inisiasi pada mencit betina diinduksi benzo(a)piren. Majalah Farmasi Indonesia, 15(1):7-12. 
24. Ong CS, Tran E, Nguyen TT, Ong CK, Lee SK, Lee JJ, Ng CP, Leong C, Huynh H. Quercetin-induced growth inhibition and cell death in nasopharyngeal carcinoma cells are associated with increase in Bad and hypophosphorylated retinoblastoma expressions. Oncol Rep 2004; 11: 727-33.

25. Porrini M, Riso P, Brusamolino A, Berti C, Guarnieri S, Visioli F. Daily intake of a formulated tomato drink affects carotenoid plasma and lymphocyte concentrations and improves cellular antioxidant protection. Br $\mathrm{J}$. Nutr. 2005; 93: 93-99.

26. Rahman I, Yang SR, Biwas SK, 2006. Current concepts of redox signaling in the lungs. Antioxid Redox Signal 8:681-9.

27. Rice-Evans CA, Miller NJ, Bolwell PG, Bramley PM, Pridham JB. The relative antioxidant activities of plantderived polyphenolic flavonoids. Free Radic Res 2005; 22: 375-83.

28. Sang SM, Lee MJ, Hou Z, 2005. Stability of tea polyphenol (-)-epigallocatechin-3-gallate and formation of dimers and epimers under common experimental conditions. J Agric Food Chem, 53: 9478-9484.

29. Selvendiran K, Koga H, Ueno T, Yoshida T, Maeyama M, Torimura T, Yano H, Kojiro M, Sata M. Luteolin promotes degradation in signal transducer and activator of transcription 3 in human hepatoma cells: an implication for the antitumor potential of flavonoids. Cancer Res 2006; 66: 4826-34.

30. Shimizu M, Deguchi A, Lim JT, Moriwaki H, Kopelovich L, Weinstein IB. (-)-Epigallocatechin gallate and polyphenon $\mathrm{E}$ inhibit growth and activation of the epidermal growth factor receptor and human epidermal growth factor receptor-2 signaling pathways in human colon cancer cells. Clin Cancer Res 2005; 11: 2735-46.

31. Soeksmanto A. Pengaruh ekstrak butanol buah tua mahkota dewa (Phaleria macrocarpa [Scheff.] Boerl.) terhadap jaringan ginjal mencit (Mus musculus). Biodiversitas 2006a; 7(3): 278-281.

32. Soeksmanto A. Pengaruh ekstrak butanol buah tua mahkota dewa (Phaleria macrocarpa [Scheff.] Boerl.) terhadap jaringan hati mencit (Mus musculus). Biodiversitas 2006b; 7(4): 340-343.

33. Sun S-Y, Numsen Hail Jr, Reuben Lotan. Apoptosis as a Novel Target for Cancer Chemoprevention. Journal of the National Cancer Institute 2004; 96(9) 662-672.

34. Surh YJ. Cancer chemoprevention with dietary phytochemicals. Nat Rev Cancer. 2003; 3:768-780.

35. Thomasset SC, Berry DP, Garcea G, Marczylo T, Steward WP and Gescher AJ, 2007. Dietary polyphenolic phytochemicals-promising cancer chemopreventive agents in humans? A review of their clinical properties. Int J Cancer 120: 451-458.

36. Wang ZY, Huang MT, Lou YR, Xie JG, Reuhl KR, Newmark HL, Ho CT, Yang CS, Conney AH. Inhibitory effects of black tea, green tea, decaffeinated black tea and decaffeinated green tea on ultraviolet B light-induced skin carcinogenesis in 7,12-dimethylbenz(a)anthracene-initiated SKH-1 mice. Cancer Res. 19945; 4: 34283435 .

37. Wattenberg LW, Wiedmann TS, Estensen RD, Zimmerman CL, Galbraith AR, Steele VE, Kelloff GJ. Chemoprevention of pulmonary carcinogenesis by brief exposures to aerosolized budesonide or beclomethasone diproprionate and by the combination of aerosolized budesonide and dietary myo-inositol. Carcinogenesis 2000; 21: 179-182.

38. Widyasari A, Riastiti Y, Astuti 1, Susilowati R, Harijadi. Efek biji mahkota dewa terhadap ekspresi caspase-3 aktif pada ce1 line Ca colon WiDr. Berkala llmu Kedokteran 2006; 38 (1): 24-29.

39. Yang CS, Wang X, Lu G, and Picinich SC, 2009. Cancer prevention by tea: animal studies, molecular mechanisms and human relevance. Nat Rev Cancer: 9(6): 429-439.

40. Yang CS, Wang ZY. Tea and cancer; a review. J Natl Cancer Inst 1993; 85: 1038-49.

41. Yang G, Wang ZY, Kim S, Liao J, Seril DN, Chen X, Smith TJ, Yang CS. Characterization of early pulmonary hyperproliferation and tumor progression and their inhibition by black tea in a 4-(methylnitrosamino)-1-(3pyridyl)-1-butanone-induced lung tumorigenesis model with A/J mice. Cancer Res. 1997; 57: 1889-94.

42. Yao LH, Jiang YM, Shi J, Tomas-Barberan FA, Datta N, Singanungsong R, Chen SS. Flavonoids I food and their health benefits. Plant Foods Hum. Nutr. 2004: 59: 113-22.

43. Zhai S, Dai R, Friedman F, Vestal R. Comparative inhibition of human cytochromes p450 $1 \mathrm{~A} 1$ and $1 \mathrm{~A} 2$ by flavonoids. Drug Metabolism and Disposition 2008; 26: 989-992.

44. Zochbauer-Muller S, Gazdar AF, Minna JD. Molecular pathogenesis of lung cancer. Annu Rev Physiol 2002; 64: 681-708. 